\title{
Antibacterial and antioxidant activities of nine de novo peptides P1-P9
}

\author{
Thitiporn Anunthawan ${ }^{1 *}$, Nida Arbsuwan ${ }^{1}$, Nutthawut meesilp ${ }^{1}$, Santi Phosri ${ }^{2}$ \\ ${ }^{1}$ Department of Applied Biology, Faculty of Sciences and Liberal Arts, Rajamangala University of Technology Isan, Nakhon Ratchasima, Thailand. \\ ${ }^{2}$ Department of Chemical Engineering, Faculty of Engineering, Burapha University, Chon Buri, Thailand.
}

\section{ARTICLE INFO \\ Received on: 10/09/2020 \\ Accepted on: 14/12/2020 \\ Available online: 05/03/2021}

\section{Key words:}

Antibacterial peptide,

Antioxidant peptide,

Antibacterial peptide design,

Short peptides, Hemolysis.

\begin{abstract}
The use of antimicrobial peptides as agents of food additives, cosmeceuticals and preservatives is becoming increasingly popular. This research reported the design of nine de novo peptides (P1-P9) and their activities against seven bacterial strains together with their antioxidant and hemolytic activities. The secondary structure of two of these peptides (P8 and P9) was also studied as well as their effects on the membrane of Staphylococcus epidermidis. The results showed that the 12 amino acid residue peptides, P8 and P9, had eight positive charges, $50 \%$ hydrophobic ratio, and 1.61 Boman index. However, their amino acid sequence and hydrophobic facet sizes were different. P8 and P9 displayed no toxicity against human red blood cells at their minimum inhibitory concentrations required to inhibit the bacterial growth of at least $90 \%$ of organisms $\left(\mathrm{MIC}_{90}\right.$ ) against Staphylococcus epidermidis and Staphylococcus aureus. P8 and P9 resulted in S. epidermidis cell blebs. The Circular dichroism spectra of P8 and P9 revealed that their structures in 50\% trifluoroethanol (TFE) were more ordered indicating the possibility of structural change in the antibacterial mechanism. Moreover, all designed peptides had antioxidant activity. All peptides except P9 had low toxicity against human red blood cells and less than $5 \%$ at concentrations higher than their half maximal inhibitory concentration $\left(\mathrm{IC}_{50}\right)$ approximately more than 8-30 times. P8 and P9 are interesting to further develop as antibiotic agents. Moreover, all peptides are interesting for antioxidant applications.
\end{abstract}

\section{INTRODUCTION}

Nowadays, antimicrobial peptides (AMPs) are of interest as new agents of food additives and preservatives due to less toxicity and good bioactivity (Ben Said et al., 2019; Wang et al., 2016a). Due to the increased development of antibacterial resistance, antibiotic alternative research has been of interest. For example, polymyxin B is a group of cyclic nonribosomal polypeptide that is isolated from the bacterium Bacillus polymyxa. It has been used as an antibiotic against Gram-negative bacteria (Michalopoulos and Falagas, 2008). Although many researchers have reported on designed antibacterial peptides, the amino acid sequences in this paper have not been reported before.

"Corresponding Author

Thitiporn Anunthawan, Department of Applied Biology, Faculty of Sciences and Liberal Arts, Rajamangala University of Technology Isan, Nakhon Ratchasima,Thailand.E-mail:Thitiporn.an@rmuti.ac.th
Commercially, most AMPs are chemically synthesized because their production is easy, it takes a short time, and a large quantity is produced. Normally, AMPs have amphiphilic properties, 2-7 net charges, and approximately $50 \%$ hydrophobic percentage (Mishra et al., 2018). Hydrophobic boundary of a designed peptide is also an important factor in antibacterial peptide design (Chen et al., 2007; Guo et al., 2013; Lee et al., 2019).

AMPs can be used to improve the shelf life of cosmeceutical or food products such as in the case of Nisin, a well-known preservative peptide. Nisin was approved by food and drug administration (FDA) in 1998 as a preservative (FDA, 1998; Hsu et al., 2004). Moreover, lysozyme peptides (LzP) are well known as natural food preservatives (Abdoub et al., 2007). Also, MDpep9 which is obtained from housefly larvae is an antibacterial peptide which is of interest to further develop as a preservative (Tang et al., 2009).

Many peptides with antioxidant activity have been isolated from food hydrolysates, plant proteins, and chemical synthesis. The short peptide (YWYPGL) obtained from casein 
hydrolysates had good antioxidant activity in superoxide, hydroxyl, and 2,2-diphenyl-1-picrylhydrazyl (DPPH) assay (Suetsuna et al., 2000). The short peptide, WYSLAMAASAI, obtained from lactalbumin, had better antioxidant activity than that of butylated hydroxyanisole (BHA) (Hernández-Ledesma et al., 2005). BHA is both an antioxidant agent and a preservative which is widely used in food, drug, and cosmeceutical applications. The chemically synthetic peptide, GWWW, showed good antioxidant activity against peroxyl radicals and peroxynitrite (Matsui et al., 2018). They are interesting as food additives because some antioxidant peptides could not be destroyed in the human digestive system (Chabance et al., 1998; Webb et al., 1990).

The aim of this study is to design ultra-short peptides with antibacterial and antioxidant activities and low toxicity by varying hydrophobic and hydrophilic facets. The various hydrophobic and hydrophilic facet sizes of the designed peptides resulting in net charge, length, and \% hydrophobic ratio differences were examined for hemolytic, antibacterial, and antioxidant activities.

\section{MATERIALS AND METHODS}

\section{Materials}

All peptides were obtained from GL Biochem (Shanghai, China). Other reagents were reagent grade.

\section{Peptide synthesis}

Ultra-short peptides were obtained from GL Biochem (Shanghai, China). They were synthesized by Fmoc solid phase. High performance liquid chromatography (HPLC) (stationary phase: C-18, mobile phase: $5 \%-20 \%$ acetone in water, time: 0-20 minutes) was performed to obtain peptides with a $95 \%$ purity level or greater. Electrospray ionization mass spectrometry (ESI-MS) chromatogram confirmed the synthesis efficiency by comparing the molecular weight of the synthesized peptides with the theoretical molecular weight of each peptide.

\section{Minimum inhibitory concentrations (MICs) and bactericidal activities}

Briefly, minimum inhibitory concentrations (MICs) and bactericidal activities were determined by using a methodology adapted from a previous report (Andrews, 2001). All testedbacterial strains were obtained from the department of medical science, Thailand. Each bacterial strain was inoculated to enter its $\log$ growth phase. The bacterial suspension was adjusted to an optical density (OD) of 0.001 at $600 \mathrm{~nm}$. The $90 \mu \mathrm{l}$ of each microorganism in Luria-Bertani broth (Himedia, India) was added to 96 -well plates. The $10 \mu \mathrm{l}$ of various peptide concentrations (twofold dilution) in $10 \mathrm{mM}$ Tris- $\mathrm{HCl}$ buffer $(\mathrm{pH} 7.4$ ) was treated. The $10 \mathrm{mM}$ Tris- $\mathrm{HCl}$ buffer $(\mathrm{pH}$ 7.4) was used as a control representing $100 \%$ growth ability. After incubation at $37^{\circ} \mathrm{C}$ for 16-18 hours, the $\mathrm{OD}_{600}$ absorbance of each well was calculated for the $90 \%$ inhibition $\left(\mathrm{MIC}_{90}\right.$ ) by using the following formula:

$$
\% \text { inhibition }=100-\frac{(\text { Abs } 2-\text { Abs } 0) \times 100}{(\text { Abs } 1-\text { Abs } 0)},
$$

where Abs 0 is the absorbance of a blank well, Abs 1 is the absorbance of a negative control (100\% bacterial growth), and Abs 2 is the absorbance of a peptide treated sample. The clear suspensions of each well $\left(\mathrm{MIC}_{90}\right)$ were further analyzed, on the $100 \%$ minimum bactericidal concentration (MBC) value, by using the drop plate technique. The concentrations without any bacterial colony were reported as $100 \% \mathrm{MBC}$.

\section{Antioxidant activity}

The antioxidant activity of all the designed peptides was determined by using the 2,2'-azino-bis(3-ethylbenzothiazoline6-sulfonic acid) (ABTS) assay. Briefly, the mixture of ABTS and potassium persulfate was prepared by dissolving ABTS and potassium persulfate in distilled water to obtain a final concentration of 7.2 and $2.6 \mathrm{mM}$, respectively. The mixture was left in the dark at room temperature for about 12 hours. The mixture was then measured at $734 \mathrm{~nm}$ and was adjusted to an absorbance of about 0.72 at $734 \mathrm{~nm}$. The $10 \mu 1$ of each peptide was incubated with $90 \mu \mathrm{l}$ of ABTS free radical suspension in a 96-well plate for 10 minutes in the darkness. Glutathione was used as a positive control and distilled water was used as a negative control The samples in 96-well plates were measured at $734 \mathrm{~nm}$. All values were subtracted from the average value of the blank wells. The percent of ABTS radical scavenging activity was calculated according to the following formula:

$$
\% \text { free radical scavenging }=100-\frac{(\operatorname{Abs} 2-\operatorname{Abs} 0) \times 100}{(\operatorname{Abs} 1-\operatorname{Abs} 0)}
$$

where Abs 0 is the absorbance at $734 \mathrm{~nm}$ of the blank well, Abs 1 is the absorbance at $734 \mathrm{~nm}$ of the negative control (100\% free radicals), and Abs 2 is the absorbance at $734 \mathrm{~nm}$ of the sample.

\section{Hemolysis}

The toxicity of all designed peptides was determined against human red blood cells. The red blood cells of a healthy human were collected and washed with phosphate-buffered saline (PBS) and then centrifuged three times at 5,000 rpm for 5 minutes each time. After that, the red blood cell suspension was adjusted to $2 \%$ red blood cells in PBS. Each peptide $(0.781-1,000 \mu \mathrm{g} / \mathrm{ml}$, $10 \mu \mathrm{l})$ was incubated with the suspension for 1 hour at $37^{\circ} \mathrm{C}$. One percent Triton X100 was treated as a positive control and PBS was treated as a negative control. The samples were then centrifuged at $5,000 \mathrm{rpm}$ for 5 minutes. The $100 \mu 1$ of suspensions was collected and measured at $570 \mathrm{~nm}$.

$$
\% \text { hemolytic activity }=\frac{(\text { Abs } 2-\text { Abs } 0) \times 100}{(\text { Abs } 1-\text { Abs } 0)}
$$

where Abs 0 is the absorbance of the negative control, Abs 1 is the absorbance at $570 \mathrm{~nm}$ of the positive control, and Abs 2 is the absorbance at $570 \mathrm{~nm}$ of the sample.

\section{Circular dichroism}

The secondary structure of P8 and P9 which had good antibacterial activity was then studied in different conditions by using circular dichroism. Shortly, each peptide was dissolved in phosphate buffer or $50 \%$ TFE in distilled water at the concentration of $0.1 \mathrm{mg} / \mathrm{ml}$. A $1 \mathrm{~mm}$ path length cell was used. The Circular dichroism (CD) spectrum data were obtained by using the Jasco J-815 CD Spectrometer. 


\section{Scanning electron microscope}

The effects of the peptides P8 and P9 on bacterial envelope change were studied by using a scanning electron microscope. Briefly, the bacterial suspension in mid-exponential growth phase was washed in PBS three times and diluted to approximately $10^{8} \mathrm{CFU} / \mathrm{ml}$ in PBS. After that, $90 \mu \mathrm{l}$ of the bacterial suspension was incubated with $10 \mu \mathrm{l}$ of each peptide in the concentration of 4-time MIC for 1 hour, $37^{\circ} \mathrm{C}$. The PBS was used as a negative control. The $20 \mu \mathrm{l}$ of each sample was deposited on 0.1 micrometer polycarbonate membrane and was fixed with 5\% glutaraldehyde for 4 hours. The samples were gradually dehydrated with ethanol series $(30 \%, 50 \%, 70 \%, 90 \%$, and $100 \%$ ethanol) for 15 minutes of each ethanol concentration. After sample drying in a vacuum for 6 hours, all samples were coated with gold. Scanning electron microscope (SEM) images were taken at low electron energies.

\section{RESULTS AND DISCUSSIONS}

\section{Peptide design}

In an ultra-short peptide design containing only two different amino acids, tryptophan represents a hydrophobic amino acid and lysine represents a positive charge amino acid. Tryptophan is found in many antibacterial peptides (Deslouches et al., 2013; Sitaram et al., 2003); therefore, it was selected to represent a hydrophobic amino acid. The $\mathrm{NH}$ of the aromatic side chain of tryptophan can form hydrogen bonds, which has a dipole moment, with the interfacial region of a membrane resulting in the peptide anchoring to the bilayer surface (Mishra et al., 2018). The reason why lysine was selected to represent a positive charge amino acid in this study is due to its selectivity as can be seen in a previous report (Anunthawan et al., 2013). Their facets were depicted by helical wheel patterns as can be seen in Figure 1 (Mól et al., 2019). Each peptide had different hydrophobic and hydrophilic facet sizes as can be seen in the helical wheel pattern (Fig. 1). Three pairs of designed peptides which were of equal lengths and various facet sizes ( $\mathrm{P} 4$ and P7, P5 and P6, and P8 and P9) and the others which were of unequal lengths and various facet sizes (P1, P2, and P3) were examined for antibacterial, antioxidant, and hemolytic activities. The chemical and physical properties of all nine peptides, named P1-P9, can be seen in Table 1 . The $\%$ hydrophobic ratio and protein-binding potential (Boman index) of all designed peptides were calculated by using an online program (APD3, 2019). All designed peptides were modified by C-terminal amidation (Strandberg et al., 2007). Their lengths were 3-15 amino acids. The net-positive charge including $\mathrm{NH}_{2}$ at both termini was from +4 to +11 . Protein-binding potential (Boman index) was 2.39 for P3, P4, and P5 and was 1.61 for P8 and P9. The hydrophobic ratio of P1 was the lowest (33\%) and the hydrophobic ratio of P2-P7 was 40\%. P8 and P9 had the highest hydrophobic ratio at $50 \%$. The designed peptides were compared to other peptide sequences stored in the antimicrobial peptide database (APD3 database) to ensure that their peptide sequences were not previously reported (Wang et al., 2016b).

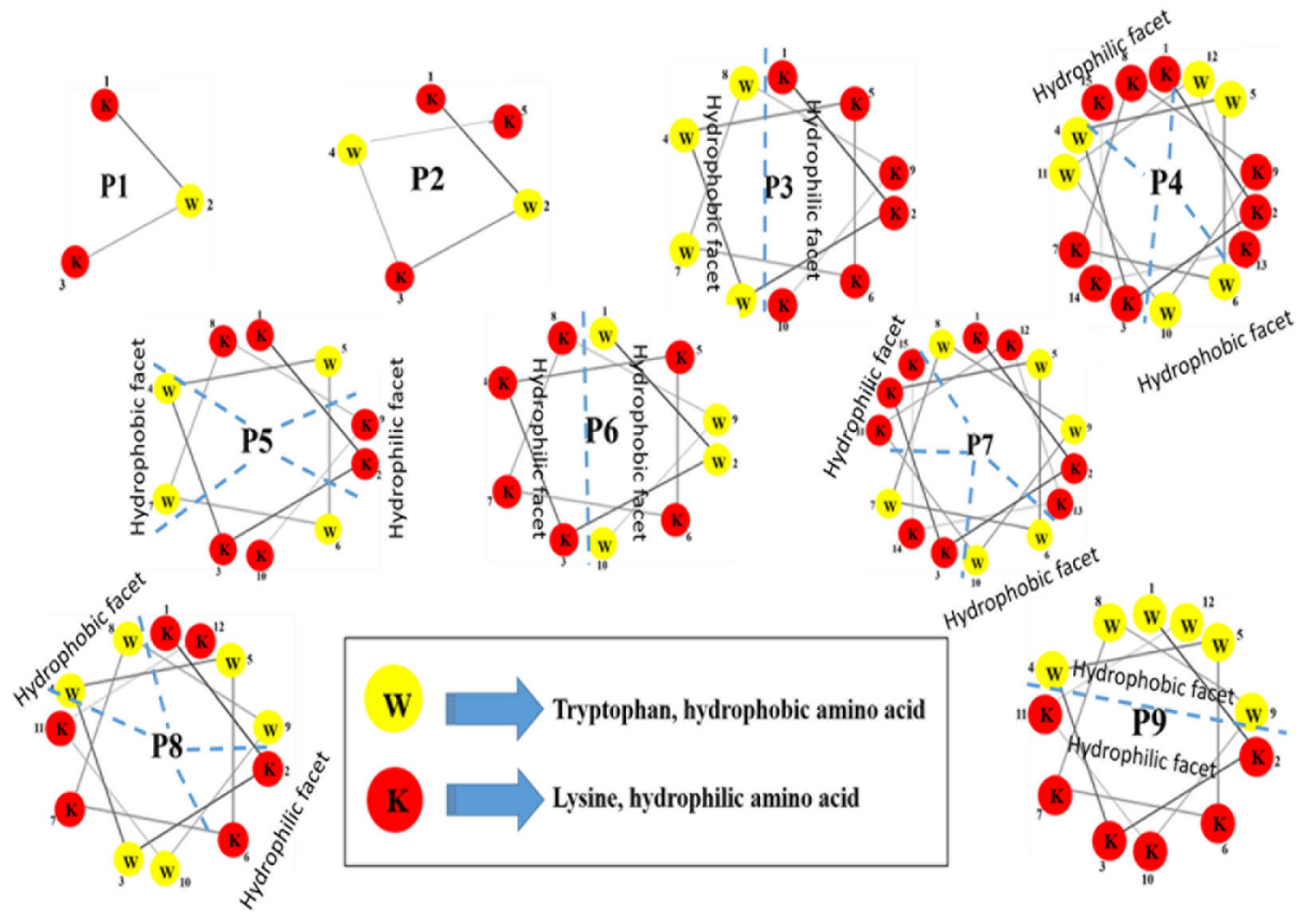

Figure 1. Helical wheel patterns of all designed peptides. 


\section{Minimum inhibitory concentrations (MICs) and bactericidal activities}

Antibacterial activity of all designed peptides was determined against seven bacterial strains (Escherichia coli DMST 15537, Escherichia coli O157:H7, Staphylococcus epidermidis DMST 5868, Pseudomonas aeruginosa DMST 5870, Staphylococcus aureus DMST 8013, Staphylococcus aureus (MRSA) DMST 4738, and Klebsiella pneumoniae DMST 37389) as can be seen in Table 2. The highest concentration of P8 and P9 $(100 \mu \mathrm{g} / \mathrm{ml})$ could not kill the largest number of bacteria. This was possibly caused by the defense activation of bacteria against the peptides or peptide aggregation (Azad et al., 2011). The peptides P8 and P9 had better antibacterial activity than the other designed peptides. P8 had $\mathrm{MIC}_{90}$ at $6.3 \mu \mathrm{g} / \mathrm{ml}$, whereas P9 had $\mathrm{MIC}_{90}$ at $3.1 \mu \mathrm{g} / \mathrm{ml}$ against $S$. epidermidis DMST 5868. Normally, $S$. epidermidis can form biofilms that grow on implants resulting in infections. For $S$. aureus DMST 8013, which causes foodborne illnesses, P8 had $\mathrm{MIC}_{90}$ at $50 \mu \mathrm{g} / \mathrm{ml}$, whereas P9 had $\mathrm{MIC}_{90}$ at $6.3 \mu \mathrm{g} / \mathrm{ml}$. Only P9 could inhibit the bacterial growth of $E$. coli $\mathrm{O} 157: \mathrm{H} 7$, which is a cause of foodborne illnesses, at $12.5 \mu \mathrm{g} / \mathrm{ml}$. However, other designed peptides needed a higher concentration for $\mathrm{MIC}_{90}$ against all bacterial strains.

P8 and P9 had the same number of amino acid residues which was 12 . They had equal hydrophobic residues (six tryptophan residues) and hydrophilic residues (six lysine residues) resulting in 50\% hydrophobic ratio, 8 positive charges, and $1.61 \mathrm{kcal} / \mathrm{mol}$ Boman index. The Boman index of P8 and P9 was lower than that of P3-P7 $(2.39 \mathrm{KJ} / \mathrm{mol})$ indicating that a high Boman index does not always result in good antibacterial activity (Boman, 2003). Comparing the sequences of P8 and P9 with other reported peptides in APD database, $\mathrm{P} 8$ and $\mathrm{P} 9$ were similar to the peptides named Inverso-CysHHC10 50\% which has antibacterial activity against $S$. aureus and $S$. epidermidis and has low toxicity toward human red blood cells (Buckholtza et al., 2016). P8 and P9 could inhibit $S$. epidermidis at 6.3 and $3.1 \mu \mathrm{g} / \mathrm{ml}$, respectively. The hydrophobic ratio of P8 and P9 was the highest among the designed peptides in this study. This may be one of the factors that increased their antibacterial activity. These results corresponded to the previous studies which reported that higher hydrophobicity or hydrophobic ratio of peptides results in higher antibacterial activity (Chen et al., 2007; Rosenfeld et al., 2010).

The difference between P8 and P9 is the amino acid sequence as can be seen in Table 1. P8 had two times an amino acid repeat pattern, KKWWW. But P9 had three times an amino acid repeat pattern, WKKW. This difference resulted in the difference in their secondary structure, hydrophobic and hydrophilic facets. P9 had a bigger hydrophobic facet than that of $\mathrm{P} 8$ resulting in its better antibacterial activity. Comparing the activities of P9 and P3, even though they had the same sizes of hydrophilic facet, P3 had no antibacterial activity indicating that its hydrophobic facet size was not suitable. The hydrophobic facet of P3 contained only four residues; this lower hydrophobic ratio has been hypothesized to be the reason for the lack of antibacterial activity (Chen et al., 2007; Rosenfeld et al., 2010).

Table 1. Biological and biophysical properties of designed peptides.

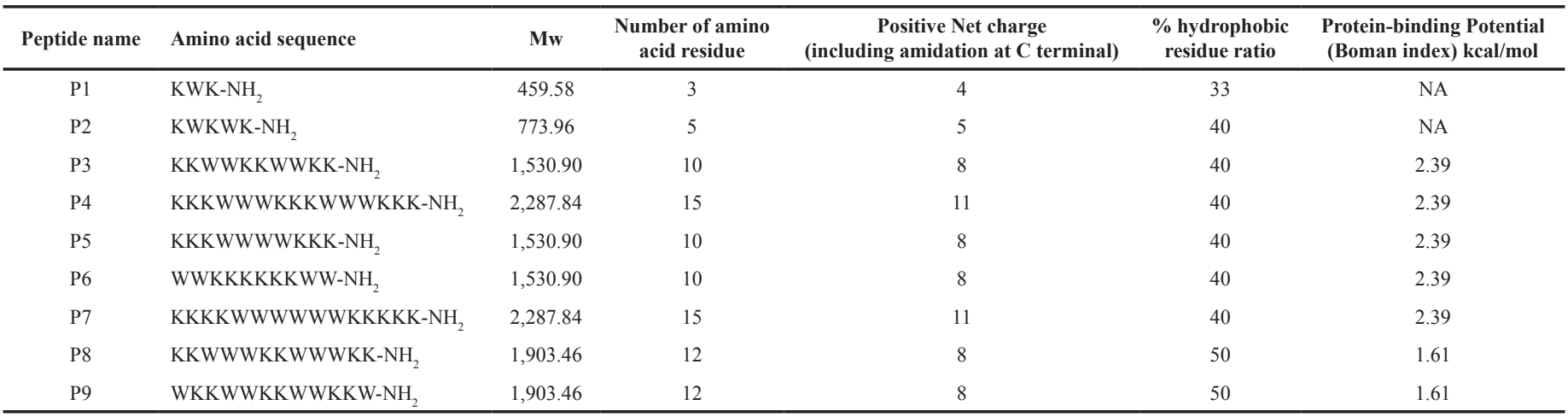

NA indicates missing data.

Table 2. Antibacterial activity of designed peptides. MICs are defined as the concentration $(\mu \mathrm{g} / \mathrm{ml})$ that inhibited bacterial growth at least by $90 \%$.

\begin{tabular}{|c|c|c|c|c|c|c|c|c|}
\hline Peptide name & Amino acid sequence & $\begin{array}{c}\text { E. coli DMST } \\
15537\end{array}$ & $\begin{array}{c}\text { E. coli } \\
\text { O157:H7 }\end{array}$ & $\begin{array}{c}\text { S. epidermidis } \\
\text { DMST } 5868\end{array}$ & $\begin{array}{l}\text { P. aeruginosa } \\
\text { DMST } 5870\end{array}$ & $\begin{array}{c}\text { S. aureus } \\
\text { DMST } 8013\end{array}$ & $\begin{array}{l}\text { S. aureus (MRSA) } \\
\text { DMST } 4738\end{array}$ & $\begin{array}{c}\text { K. pneumoniae } \\
\text { DMST } 37389\end{array}$ \\
\hline $\mathrm{P} 1$ & $\mathrm{KWK}_{-\mathrm{NH}_{2}}$ & $>100$ & $>100$ & $>100$ & $>100$ & $>100$ & $>100$ & $>100$ \\
\hline $\mathrm{P} 2$ & $\mathrm{KWKWK}-\mathrm{NH}_{2}$ & $>100$ & $>100$ & $>100$ & $>100$ & $>100$ & $>100$ & $>100$ \\
\hline P3 & KKWWKKWWKK-NH & 50 & 50 & $>100$ & $>100$ & $>100$ & $>100$ & $>100$ \\
\hline P4 & KKKWWWKKKWWWKKK-NH ${ }_{2}$ & $>100$ & $>100$ & $>100$ & $>100$ & $>100$ & $>100$ & $>100$ \\
\hline P5 & KKKWWWWKKK-NH & $>100$ & $>100$ & $>100$ & $>100$ & $>100$ & $>100$ & $>100$ \\
\hline P6 & WWKKKKKKWW-NH & 50 & 50 & $>100$ & $>100$ & $>100$ & $>100$ & $>100$ \\
\hline P7 & KKKKWWWWWWKKKKK-NH & $>100$ & $>100$ & $>100$ & $>100$ & $>100$ & $>100$ & $>100$ \\
\hline P8 & KKWWWKKWWWKK-NH & 12.5 & $>100$ & 6.3 & $>100$ & 50 & $>100$ & $>100$ \\
\hline P9 & WKKWWKKWWKKW-NH & $6.3^{\mathrm{a}}$ & 12.5 & 3.1 & 12.5 & 6.3 & 12.5 & 12.5 \\
\hline
\end{tabular}

${ }^{\mathrm{a}}$ Indicates $100 \%$ bacterial cell death. 
However, P4 and P7, containing 15 amino acid residues (more than the amino acid residue number of P8 and P9), had poor antibacterial activity against all bacterial strains indicating that a longer peptide chain and a more positive charge do not always improve antibacterial activity.

\section{Antioxidant activity}

All designed peptides had antioxidant activity higher than approximately $80 \%$ free radical scavenging $(<20 \%$ remaining free radicals) at $0.1 \mathrm{mg} / \mathrm{ml} . \mathrm{IC}_{50}$ of all peptides are shown in Table 3. The reason why all designed peptides have antioxidant activity is due to the tryptophan property, which has an indole ring for free radical scavenging (Zou et al., 2016). P3 demonstrated the best antioxidant activity among the designed peptides, with $\mathrm{IC}_{50}$ of 3.2 $\mu \mathrm{g} / \mathrm{ml}$ or $2.07 \mu \mathrm{M}$. A comparison between P9 and P3 which had the same hydrophilic facet size and smaller hydrophobic facet showed that P3 had a better antioxidant activity. This indicates that the activity may not depend on hydrophobic facet size. P1, containing three amino acids, displayed $\mathrm{IC}_{50}$ almost equal to glutathione which is the positive control $(6.1 \mu \mathrm{g} / \mathrm{ml}, 13.3 \mu \mathrm{M})$. P2, the slightly longer peptide (with five residues), had an antioxidant activity slightly better than that of P1. A comparison of the antioxidant activities of the three pairs of designed peptides which had the same length (P4 and P7, P5 and P6, and P8 and P9) showed that only the pair of

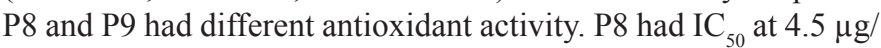
$\mathrm{ml}$ or $2.35 \mu \mathrm{M}$, which was lower than that of P9 $(10.8 \mu \mathrm{g} / \mathrm{ml}, 5.67$ $\mu \mathrm{M})$. Even though P8 and P9 had the same chemical properties, their hydrophobic, hydrophilic facets, and antioxidant activities were different. The larger hydrophobic facet sizes as visualized by the helical wheel had no direct effect on a higher antioxidant activity as can be seen in the comparison of the activities and the facets of the P3 and P9 and P8 and P9 pairs.

\section{Hemolysis}

In in vitro selectivity index, an antibiotic candidate should be nontoxic against human cells at the concentration required to achieve a therapeutic effect. All designed peptides except P9 had hemolytic activity lower than $5 \%$ at the concentration of 100 $\mu \mathrm{g} / \mathrm{ml}$ as can be seen in Figure 2. P9 had a bigger hydrophobic region than that of $\mathrm{P} 8$; its toxicity against human red blood cells was higher. These results are consistent with the previous study which reported that higher hydrophobicity of the nonpolar face of amphipathic peptides results in higher hemolytic activity (Chen et al., 2007). Moreover, P9 had toxicity against human red blood cells of approximately $20 \%$ at $100 \mu \mathrm{g} / \mathrm{ml}$ and had no hemolytic activity at its $\mathrm{MIC}_{90}$ against $S$. epidermidis $(3.1 \mu \mathrm{g} / \mathrm{ml})$. For antioxidant activity, P2, P3, and P8 in particular had low toxicity toward human red blood cells, less than $5 \%$ at the concentration $(100 \mu \mathrm{g} / \mathrm{ml})$, and greater than their $\mathrm{IC}_{50}$, approximately more than 20-30 times.

\section{Circular dichroism}

The conformational change of antibacterial peptides is reported in a previous study (Andrushchenko et al., 2006). A secondary conformational analysis was performed to consider whether there was a conformational change when expressed in a hydrophobic environment compared to a conformation in hydrophilic environment. CD experiments of P8 and P9 were performed in phosphate buffer $(\mathrm{pH}$ 7.4) indicating no defined secondary structure. Fifty percent of TFE, which is a hydrophobic solution, induced maximum $\alpha$ helix structure in peptides. For P8, an $\alpha$ helix conformation was observed in $50 \%$ TFE, indicating a coil-to- $\alpha$-helix transition upon interaction with hydrophobic environments as can be seen in Figure 3A. Also, the secondary structure of P9 was more ordered as a helix structure as can be seen in Figure 3B, observed in $50 \%$ TFE. It corresponds to the helical wheel pattern of P9 that its hydrophobic and hydrophilic facets are equal. The results suggest that their secondary structures may change when interacting with an antibacterial membrane.

$\mathbf{A}$

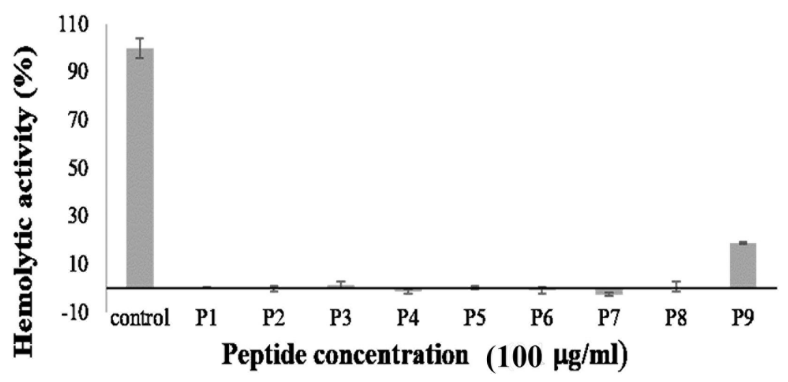

B

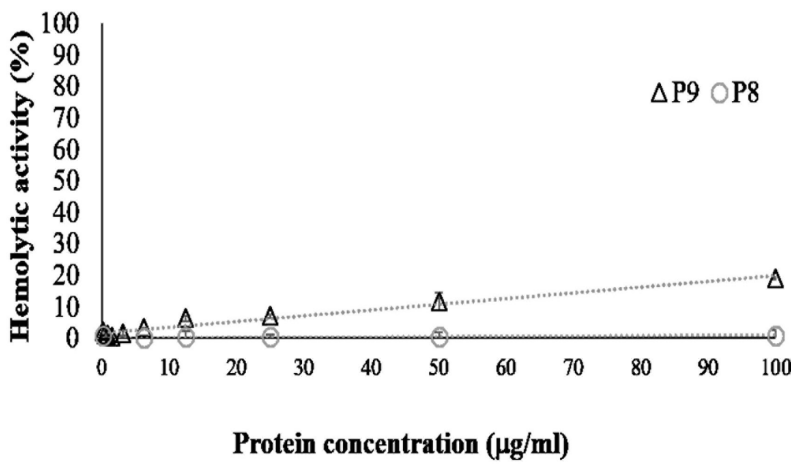

Figure 2. Hemolytic activities of de novo short peptides. Hemolytic activities of all designed peptides at $100 \mu \mathrm{g} / \mathrm{ml}$ are shown in 2A. Only P9 had toxicity toward human red blood cells. 2B reveals comparing hemolytic activities of P8 and P9. While P8 had no hemolytic activities at all tested concentrations, P9 had toxicity less than $20 \%$ at $50 \mu \mathrm{g} / \mathrm{ml}$.

Table 3. Antioxidant activity in $\mathrm{IC}_{50}(\mu \mathrm{g} / \mathrm{ml})$ of each peptide.

\begin{tabular}{|c|c|c|c|c|c|c|c|c|c|c|}
\hline Peptide name & glutathione & P1 & P2 & P3 & P4 & P5 & P6 & P7 & P8 & P9 \\
\hline $\mathrm{IC}_{50}(\mu \mathrm{g} / \mathrm{ml})$ & 3.3 & 6.1 & 4.8 & 3.2 & 12.5 & 6.5 & 5.3 & 11.9 & 4.5 & 10.8 \\
\hline Amino acid residue & 3 & 3 & 5 & 10 & 15 & 10 & 10 & 15 & 12 & 12 \\
\hline $\operatorname{MHC}^{\mathrm{a}}(\mu \mathrm{g} / \mathrm{ml}) / \mathrm{IC}_{50}(\mu \mathrm{g} / \mathrm{ml})$ & NA & $>16$ & $>21$ & $>31$ & $>8$ & $>15$ & $>19$ & $>8$ & $>22$ & 0.6 \\
\hline
\end{tabular}

NA indicates missing data.

${ }^{a}$ Minimum hemolytic activity defines $\leq 5 \%$ hemolytic activity. $>$ indicates no hemolytic activity at $100 \mu \mathrm{g} / \mathrm{ml}$. 

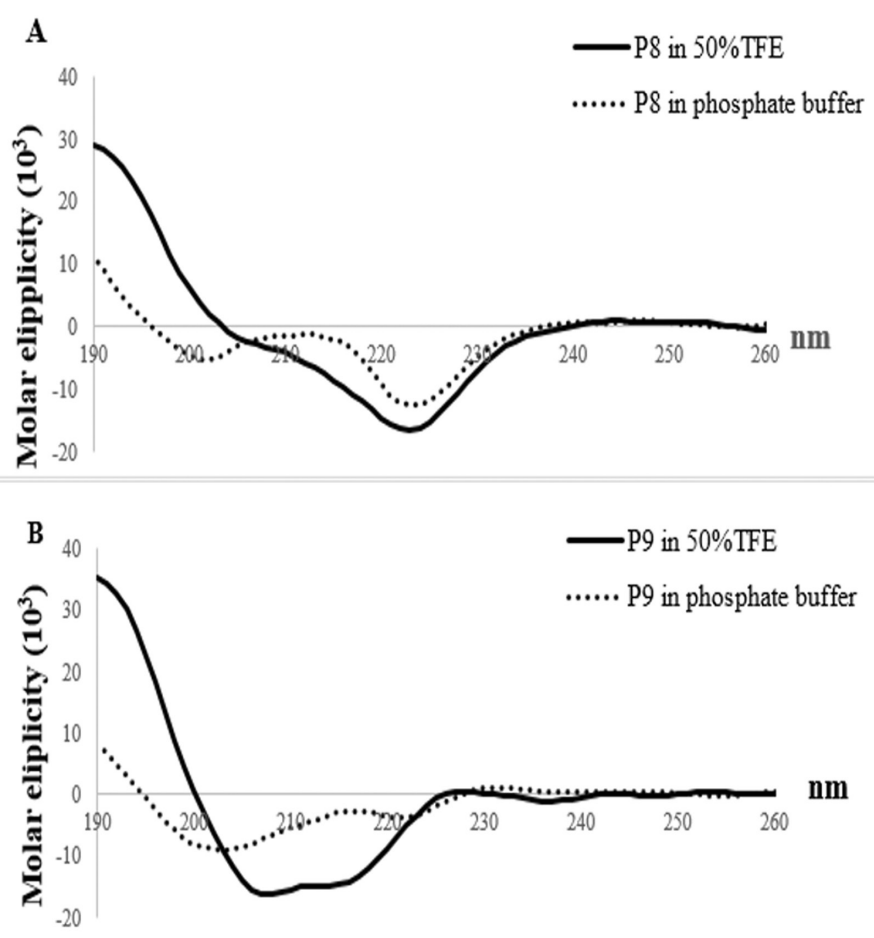

Figure 3. Structure analysis of $\mathrm{P} 8$ and $\mathrm{P} 9$. The spectra (a black line) in 50\% TFE were obtained at a peptide concentration of $0.1 \mathrm{mg} / \mathrm{ml}$. The spectra (a black dot line) in water were obtained at $0.1 \mathrm{mg} / \mathrm{ml}$. P8 (A) has unstructured conformation in water (a hydrophilic environment), whereas it presents $\alpha$-helix structure in $50 \%$ TFE (a hydrophobic environment). P9 (B) has unstructured conformation in water (a hydrophilic environment), whereas it presents $\alpha$-helix structure in $50 \%$ TFE (a hydrophobic environment).

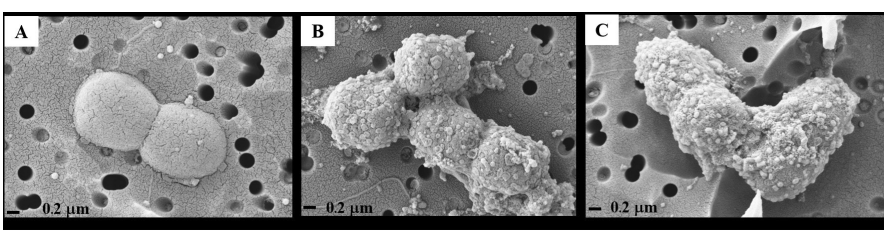

Figure 4. SEM images show the effects of P8 and P9 on S. epidermidis. The negative control which is PBS buffer without peptide is displayed in the A panel. The B and C panels visualized the bacterial cells incubating with P8 and $\mathrm{P} 9$, respectively. The bacterial cells were treated with each peptide at a final concentration of $0.1 \mathrm{mg} / \mathrm{ml}$.

\section{Scanning electron microscope}

The effects of P8 and P9 on the envelope were observed. As P8 and P9 had the best MIC against $S$. epidermidis, they were selected to be studied and it was found that even though they had different facet sizes and different bacterial activities, they could make cell wall blebs as can be seen in Figure 4. These blebs may result in bacterial membrane pores and finally cell deaths (Chileveru et al., 2015).

\section{CONCLUSION}

In conclusion, not only the net charge and $\%$ hydrophobic ratio but also hydrophobic facet size is important factors for antibacterial peptide design. P9 had less than 5\% toxicity toward human red blood cells at $6.3 \mu \mathrm{g} / \mathrm{ml}$ which was higher than its MIC against $S$. epidermidis DMST 5868, approximately 2 times. All designed peptides exhibited antioxidant activity. P2, P3, and P8 in particular had low toxicity toward human red blood cells, less than $5 \%$ at the concentration $(100 \mu \mathrm{g} / \mathrm{ml})$, and higher than their $\mathrm{IC}_{50}$, approximately more than 20-30 times. All designed peptides are interesting to further develop in antioxidant applications. Also, P8 and P9 are interesting to further develop as antibiotic agents.

\section{ACKNOWLEDGMENTS}

The authors would like to thank National Research Council of Thailand and Rajamangala University of Technology Isan for financial assistance. Also, they would like to thank Nakhon Ratchasima Rajabhat University for providing the microplate reader. Finally, they would like to thank Assoc. Prof. Dr. Chartchai Krittanai, Institute of Molecular Biosciences, Mahidol University, for providing some chemical reagents of $\mathrm{CD}$.

\section{CONFLICT OF INTEREST}

The authors declare that they have no known competing financial interests or personal relationships that could appear to influence the work reported in this paper.

\section{AUTHOR CONTRIBUTIONS}

All authors made substantial contributions to conception and design, acquisition of data, or analysis and interpretation of data; took part in drafting the article or revising it critically for important intellectual content; agreed to submit to the current journal; gave final approval of the version to be published; and agree to be accountable for all aspects of the work. All the authors are eligible to be an author as per the international committee of medical journal editors (ICMJE) requirements/guidelines.

\section{ETHICAL APPROVALS}

This study does not involve experiments on animals or human subjects.

\section{PUBLISHER'S NOTE}

This journal remains neutral with regard to jurisdictional claims in published institutional affiliation.

\section{REFERENCES}

Abdoub AM, Higashiguchia S, Aboueleinin AM, Kim M, Ibrahim HR. Antimicrobial peptides derived from hen egg lysozyme with inhibitory effect against Bacillus species. Food Control, 2007; 18(2):173-8.

Andrews JM. Determination of minimum inhibitory concentrations. J Antimicrob Chemother, 2001; 48:5-16.

Andrushchenko VV, Vogel HJ, Prenner EJ. Solvent-dependent structure of two tryptophan-rich antimicrobial peptides and their analogs studied by FTIR and CD spectroscopy. Biochim Biophys Acta, 2006; 1758:1596-608.

Anunthawan T, Yaraksa N, Phosri S, Theansungnoen T, Daduang S, Dhiravisit A, Klaynongsruang, S. Improving the antibacterial activity and selectivity of an ultra short peptide by hydrophobic and hydrophilic amino acid stretches. Bioorg Med Chem Lett, 2013; 23(16):4657-4662.

APD3. Antimicrobial peptide calculator and predictor. 2019. Available via http://aps.unmc.edu/AP/prediction/prediction_main.php (Accessed 01 January 2019). 
Azad MA, Huttunen-Hennelly HEK, Friedman CR. Bioactivity and the first transmission electron microscopy immunogold studies of short de novo-designed antimicrobial peptides. Antimicrob Agents Chemother, 2011; 55:2137-45.

Ben Said L, Fliss I, Offret C, Beaulieu L. Antimicrobial peptides: the new generation of food additives. Encyclopedia Food Chem, 2019; 3:576-82.

Boman H. Antibacterial peptides: basic facts and emerging concepts. Intern Med J, 2003; 254:197-215.

Buckholtza GA, Regera NA, Anderton WD, Schimoler PJ, Roudebush SL, Meng WS, Miller MC, Gawalt ES. Reducing Escherichia coli growth on a composite biomaterial by a surface immobilized antimicrobial peptide. Mater Sci Eng C, 2016; 65:126-34.

Chabance B, Marteau P, Rambaud JC, Migliore-Samour D, Boynard M, Perrotin P, Guillet R, Jollès P, Fiat AM. Casein peptide release and passage to the blood in humans during digestion of milk or yogurt. Biochimie, 1998; 80(2):155-65.

Chen Y, Guarnieri MT, Vasil AI, Vasil ML, Mant CT, Hodges RS. Role of peptide hydrophobicity in the mechanism of action of $\alpha$-helical antimicrobial peptides. Antimicrob Agents Chemother, 2007; 51(4):1398-406.

Chileveru HR, Lim SA, Chairatana C, Wommack AJ, Chiang I-L, Nolan EM. Visualizing attack of Escherichia coli by the antimicrobial peptide human Defensin 5. Biochemistry, 2015; 54(9):1767-77.

Deslouches B, Steckbeck JD, Craigo JK, Doi Y, Mietzner TA, Montelaroa RC. Rational design of engineered cationic antimicrobial peptides consisting exclusively of arginine and tryptophan, and their activity against multidrug-resistant pathogens. Antimicrob Agents Chemother, 2013; 57:2511-21.

FDA. Nisin preparation: affirmation of GRAS status as a direct human food ingredient. Fed Regist, 1998; 53:12247.

Guo X, Ma C, Du Q, Wei R, Wang L, Zhou M, Chen T, Shaw C. Two peptides, TsAP-1 and TsAP-2, from the venom of the Brazilian yellow scorpion, Tityus serrulatus: evaluation of their antimicrobial and anticancer activities. Biochimie, 2013; 95(9):1784-94.

Hernández-Ledesma B, Dávalos A, Bartolomé B, Amigo L. Preparation of antioxidant enzymatic hydrolysates from alpha-lactalbumin and beta-lactoglobulin. Identification of active peptides by HPLC-MS/MS. J Agric Food Chem, 2005; 53(3):588-93.

Hsu ST, Breukink E, Tischenko E, Lutters MA, de Kruijff B, Kaptein R, Bonvin AMJJ, Nuland NAJ. The nisin-lipid II complex reveals a pyrophosphate cage that provides a blueprint for novel antibiotics. Nat Struct Mol Biol, 2004; 11:963-7.

Lee PC, Chu CC, Tsai YJ, Chuang YC, Lung FD. Design, synthesis, and antimicrobial activities of novel functional peptides against Gram-positive and Gram-negative bacteria. Chem Biol Drug Des, 2019; 94(2):1537-44
Matsui R, Honda R, Kanome M, Hagiwara A, Matsuda Y, Togitani T, Ikemoto N, Terashimaet M. Designing antioxidant peptides based on the antioxidant properties of the amino acid side-chains. Food Chem, 2018; 245:750-5

Michalopoulos A, Falagas ME. Colistin and polymyxin B in critical care. Crit Care Clin, 2008; 24:377-91.

Mishra AK, Choi J, Moon E, Baek KH. Tryptophan-rich and proline-rich antimicrobial peptides. Molecules, 2018; 23:815.

Mól AR, Fontes W, Castro MS. NetWheels: Peptides helical wheel and net projections maker. 2019. Available via http://lbqp.unb.br/ NetWheels/ (Accessed 01 January 2019).

Rosenfeld Y, Lev N, Shai Y. Effect of the hydrophobicity to net positive charge ratio on antibacterial and anti-endotoxin activities of structurally similar antimicrobial peptides. Biochemistry, 2010; 49:853-61.

Sitaram N, Subbalakshmi C, Nagaraj R. Indolicidin, a 13-residue basic antimicrobial peptide rich in tryptophan and proline, interacts with $\mathrm{Ca}^{(2+)}$-calmodulin. Biochem Biophys Res Commun, 2003; 309:879-84.

Strandberg E, Tiltak D, Ieronimo M, Kanithasen N, Wadhwani $\mathrm{P}$, Ulrich SA. Influence of C-terminal amidation on the antimicrobial and hemolytic activities of cationic $\alpha$-helical peptides. Pure Appl Chem, 2007; 79(4):717-28

Suetsuna K, Ukeda $\mathrm{H}$, Ochi $\mathrm{H}$. Isolation and characterization of free radical scavenging activities peptides derived from casein. J Nutr Biochem, 2000; 11(3):128-31.

Tang YL, Shi YH, Zhao W, Hao G, Le GW. Discovery of a novel antimicrobial peptide using membrane binding-based approach. Food Control, 2009; 20(2):149-56.

Wang G, Li X, Wang Z. APD3: the antimicrobial peptide database as a tool for research and education. Nucleic Acids Res, 2016b; 44(D1):D1087-93.

Wang S, Zeng X, Yang Q, Qiao S. Antimicrobial peptides as potential alternatives to antibiotics in food animal industry. Int J Mol Sci, 2016a; 17(603):1-12.

Webb KE Jr. Intestinal absorption of protein hydrolysis products: a review. J Anim Sci, 1990; 68(9):3011-22.

Zou TB, He TP, Li HB, Tang HW, Xia EQ. The structure-activity relationship of the antioxidant peptides from natural proteins. Molecules, $2016 ; 21: 72$.

How to cite this article:

Anunthawan T, Arbsuwan N, Meesilp N, Phosri S. Antibacterial and antioxidant activities of nine de novo peptides P1-P9. J Appl Pharm Sci, 2021; 11(03):107-113. 